they might be; they tried to bring modern discoveries to the attention of all citizens capable of understanding them and using them ; and, of course, they taught undergraduates. Research, adult education and undergraduate teaching were to be equally important. They are to this day. But we must never forget that many of the best American and English engineers have been educated in the great technical universities of Europe. Furthermore, America imported the new European academic traditions along with her scientists and engineers. They had studied practical problems for years, but it was Germany which showed America that pure research could be useful and important to American universities. University research has grown so much since the war that it dominates the entire university system and has changed the very nature of universities. In 1938, the M.I.T. spent about $\$ 140,000$ on research. Last year they spent about $\$ 140$ milliona thousand times as much, and about as much as all our English universities put together.

"Any well-established American university, or any well-known research worker, can persuade some government department or other to invite him to accept a contract to do something that he has already decided that he wants to do anyway. But whenever the Federal Govern. ment decides that some burning problem must be studied forthwith their advisers always know of some university, somewhere, which would like to oblige, and build up its graduate school and perhaps become famous in the process. You may say that the Government has taken over the American universities. In a sense this is true; at the same time the universities have taken over the central government and the whole nature and structure of American government has been transformed. They have in the process produced a new type of society, a new machinery of government unlike anything $I$ have seen anywhere else. The universities themselves are an essential component of this new machine. The system depends on free and frequent interchange of staff between the Government, business and academic world.

"Russian universities all understand very clearly that they are an essential component of society and that they exist to serve it. Their organization is quite unlike any. thing in America, but it ensures that research and teaching are intimately associated at all stages. Russian universities, research stations and industrial plants are in fact separate and distinct, but it is very hard for a visitor to be sure where one ends and the other begins ; they are all part of a single vast educational and productive machine. But since it would be quite impossible to describe so complex a country as Russia, even if I understood it, I must concentrate on the one principle which seems to me to underlie everything they do. To-day the Russians more than any other people seem to be obsessed by the importance of associating theory with practice, and they have shown extraordinary ingenuity in developing an educational machine to do what they want. About ten years ago at a time of rapid university expansion the Russians began to fear that some of their university students might become a race apart, unaware of their obligations to society, or of the relevance of their studies in preparation for life. The government decided that young people ought to take a job for two years after leaving school before they could be admitted to a university. The Russians find that their students understand the practical importance of their theory and appreciate the great good fortune which has sent them to a university.

"I would like now to speak about adult education. At this moment in time the total amount of scientific knowledge in the world is doubling every fifteen years, three-quarters of all the scientists who ever lived are alive and practising to-day and half of what a man learns as an undergraduate is more or less useless after 10 years or so. It is essential that every professional man should realize that he will have to be educated and re-educated throughout his whole working life. The growth of education and re-education for adults in America has been explosively rapid. There are courses, both professional and non-professional, in everything from engineering to painting, both liberal studies and vocational training. The Russians have developed similar programmes on an enormous scale. Almost half of all Russian students do some of their work by correspondence. All universities run suitable courses. Almost anyone in America or in Russia or in Sweden can learn almost any subject which interests him, either in a university, in a small class specially arranged for him by the local university, or by correspondence. England and Australia must not lag behind their industrial competitors.

"It is essential that the universities should help to decide how their own recruits are educated. In other words, the universities must study the schools. If they do not there will be gaps between the world of teaching and the world of practical affairs. I think that all academic institutions, be they schools or universities, have a tendency to isolate themselves from the world, and to ignore the practical implications of the work they do. Up to a point, of course, this process is inevitable, and it is in a sense the very secret of their academic achievement. But in excess it can be dangerous, and even fatal. How, therefore, are Australian and English universities to ensure that what they teach is real, is exciting, changing and contemporary? Surely it must be by associating the university world as closely as possible with the worlds of industry, of commerce and of manufacture. In other words, the interest of the university work for the students, and the value of all academic disciplines, are at stake in this one principle which I have adumbrated, namely that the universities must study the problems of society, or they may lose the intellectual distinction upon which rests their claim to the support which society has given them."

\title{
OBITUARY
}

\section{Dr. W. J. Hall, C.M.G., M.C.}

WILFRID JoHN HALL, formerly director of the Commonwealth Institute of Entomology, died suddenly at Kaduna, Nigeria, where he was visiting his son, on January 13, 1965 , at the age of seventy-two.

Hall was educated at St. Paul's School and the Imperial College of Science and Technology. He gained his A.R.C.S. in 1914, and almost immediately joined the army, in which he served until 1919, being decorated with the Military Cross and attaining the rank of major. In 1919 he joined the Ministry of Agriculture, Egypt, as ontomologist. There he became involved in the study of the systematics, biology and control of scale insects, interests that were to remain throughout his career. In 1927 he was appointed by the British South Africa Company to deal with the insect problems of their extensive citrus estates in Rhodesia. His demonstration of the economic value of basing plantation management on the results of proper scientific investigation led to the establishment, in 1930, of the Mazoe Citrus Experiment Station, with a small but well-balanced research staff under his direction, and in 1933 he also assumed the responsibility of supcrintendent of the Company's estates.

He returned to England in 1943 to join the Common. wealth Institute of Entomology, of which he became assistant director in 1944 and director in 1946. To this post he brought an unusual and apposite combination of scientific talents and experience, a first-hand appreciation 
of the information needs of the entomologist working in comparative isolation overseas, and a shrewd business sense, which stood him in good stead in the management of the Institute's expanding activities. The Review of Applied Entomology, under his direction, then had to deal with the flood of information arising from the development of the organic insecticides, and his responsibilities for the Bulletin of Entomological Research, the Institute's identification service and periodical Commonwealth Entomological Conferences brought him into direct touch with entomologists throughout the Commonwealth. At this time, too, the United Kingdom, through Colonial Development and Welfare funds, was developing a massive programme of research in the then dependent territories, much of it concerned with entomological problems on which Hall's advice was sought. He served on numerous official bodies, including the Colonial Research Council, the Committee for Colonial Agricultural, Animal Health and Forestry Research, and the Colonial Insecticides Research Committee, of which he was the first chairman. He was also a member of the Sudan Agricultural Advisory Committee. He was instrumental in creating the Pool of Entomologists and the Termite Research Unit, both attached to the Institute, and played a large part in establishing the Inter-African Phytosanitary Commission. He was created C.M.G. in 1951 and was a Fellow of the Royal Entomological Society of London from 1921, and its president in 1955-56.

Although much of Hall's career was taken up with severely practical aspects of applied entomology or with administrative and advisory duties, he maintained a lifelong interest in taxonomy, specializing in the Coccoidea, on which he was an authority. It was probably his confrontation, on his first assignment in Egypt, with the ravages of the Hibiscus mealybug, the true identity of which was not then recognized, that led him to study the scale insects. Encouraged by E. E. Green, one of the outstanding coccidiologists of that time, his interest in the group grew quickly, and by 1927 he had recorded, in numerous papers, 127 Egyptian species, 41 of them described as now. He also broke new ground with an important work, published in 1926, on the aphids of Egypt. On reaching Rhodesia he set about a study of its then virtually unknown scale-insect fauna. $\mathrm{He}$ maintained a steady output of papers of the highest quality over the next sixteen years, recording 186 species from the territory, including descriptions of 98 new species. He was awarded the degree of Ph.D. by the University of London in 1927, and that of D.Se. in 1930.

On joining the Institute of Entomology he had at hand the collections of the British Museum (Natural History) and was able to extend his studies. In 1946 he published a revision of the Ethiopian Diaspidini, his most notable work, and of inestimable value to-day. His taxonomic work was halted during his directorship, but not his interest, and after his retirement in $1958 \mathrm{he}$ carried on part-time work on the British Museum collections, which he had himself substantially enriched, and collaborated in a further paper.

A man of generous build and heart, modest and unfailingly helpful to others, Hall won the respect and affection of all who knew and worked with him. His last years were clouded by the death of his wife, to whom he was deeply devoted, in 1961, and by the loss of his right eye, but despite this latter handicap, which he bore with characteristic fortitude, he continued to do further collecting, and was so engaged shortly before his death.

E. O. Pearson

\section{NEWS and VIEWS}

Additional Chair of Physics in the University of Leeds : Prof. J. S. Dugdale

DR. J. S. Dugdale, a principal research officer in the Division of Pure Physics at the National Research Council of Canada, has been appointed to an additional chair of physics in the University of Leeds. Dr. Dugdale, who is forty-three and a native of Yorkshire, studied physics at Oxford and took a shortened war-time degree in 1942. From 1942 until 1946 he served as a radar officer in the Royal Air Force and then returned to Oxford. In 1948 he began research work with Prof. F. E. Simon on the thermodynamic properties and melting curve of solid helium. In 1951 Dr. Dugdale joined the National Research Council of Canada as a Postdoctorate Fellow, working on specific heats of solids at low temperature in the Surface Chemistry Group. After the termination of his fellowship he transferred to the staff of the Solid State Physics Group under Dr. D. K. C. MacDonald. Following the untimely death of Dr. MacDonald in 1963 he was appointed head of this group and was able to show his gifts as leader of a research group. Dr. Dugdale's own research has been devoted to the effects of pressure at low temperatures on the properties of solids, and especially on the transport properties of metals. His work in this field has gained him a world-wide reputation. He was elected a Fellow of the Royal Society of Canada in 1964.

\section{Chemistry in the University of Leicester :}

\section{Prof. L. Hunter}

Prof. L. Hunter is retiring from the position of professor and head of the Department of Chemistry in the University of Leicester in September. He joined Leicester from the University College of North Wales, Bangor, in
1925, and he was responsible for founding the Chemistry Department in the University College, Leicester. Almost single-handed, he devoted the first years to establishing and consolidating it, and even prior to the Second World War there was a vigorous and steadily growing research school. The main lines of research were on the chemistry of the hydrogen bond, particularly as it concerns molecular association and tautomerism, and the chemistry of chelate metallic derivatives of organic compounds. In 1946, Prof. Hunter was elected to the newly created chair of chemistry, and the post-war years saw a steady expansion in the size of the Department. He was responsible for the supervision of the planning of new buildings, and the Department moved from its very cramped quarters in 1960. This change, together with the creation of a second chair (in physical chemistry), gave further impetus to growth in student numbers and in the range and volume of postgraduate work. Two new chairs have been established at the University of Leicester (organic and inorganic chemistry) to take effect on his retirement (see Nature, 205, 1159; $206,770 ; 1965)$. Apart from his work in the Department, Prof. Hunter has taken a prominent part in the main lines of development of the University of Leicester; he was its Vice-Principal from 1952 until 1957 and Pro-Vice-Chancellor from 1957 until 1960. The University will lose an honoured and devoted servant. $\mathrm{He}$ is also a vice-president of the Royal Institute of Chemistry; he has served on the Council of the Chemical Society and has been secretary and recorder of Section B of the British Association for the Advancement of Science.

\section{Elementary Particle Physics in the University of Oxford : \\ Prof. D. H. Perkins}

Dr. D. H. Perkins has been appointed professor of elementary particle physics in the University of Oxford 